\title{
Indigenous or Blended Model for South Asian Social Work?
}

\author{
Dr Venkat Rao Pulla, ${ }^{+*}$ Dr Tulshi Kumar Das ${ }^{*}$ and Dr Bala Raju Nikkú
}

\section{Abstract}

An argument about indigenous social work education often surfaces in South Asian schools of social work. In this study, central concerns around the indigenous argument, together with a review of the pervasive influence of the western model of social work in Asia is undertaken.

The three author- research team, utilised a methodology that featured a desk review and an analysis of communications with select South Asian scholars and academics that were respondents for the study. Additionally, the authors present their personal reflections, that prudently address their positionality and reflexivity.

The primary finding in this research paper is that the legacy of Western-influenced social work education is thriving within the region, despite criticism from different quarters about its effectiveness. The secondary finding is the admittance by respondent academics in Bangladesh, Sri Lanka, India and Nepal that relevant to their societal context, limited adaptations have been introduced and are working in their respective countries. The current research provided an opportunity to research participants to view and summarily reject claims by certain bogies that western influence in social work is solely responsible for lack of cultural appropriation within the curriculum in South Asia. The study suggests that there is a lot that can take place by way of adaptation without sacrificing the cultural elements while rearranging the social work curriculum within the region. The authors strongly advocate a blended approach as a suitable course of moderation in the re-construction attempts of social work futures in South Asia.

Keywords: Indigenous Social Work; Blended Social Work; Social Work Curriculum; South Asia

\footnotetext{
${ }^{\dagger}$ Foundation Professor, Brisbane Institute of Strengths Based Practice and Adjunct Senior Research Fellow Institute for Land Water and Society, Charles Sturt University, Albury-Wodonga, NSW, 2640

${ }^{*}$ Corresponding Author, Email: dr.venkat.pulla@gmail.com

¥Professor Tulshi Kumar Das, Department of Social Work,Shahjalal University of Science \& Technology, Sylhet-3114, Bangladesh, Emails: tulshikumardas@gmail.com and dastulshi-scw@sust.edu

í Assistant Professor, School of Social Work and Human Service, Faculty of Education and Social Work at Thompson Rivers University, Kamloops, BC, Canada, Email: brnikku@tru.ca

(C) 2020 Pulla et al. This is an Open Access article distributed under the terms of the Creative Commons Attribution License (http://creativecommons.org/licenses/by/2.0), which permits unrestricted use, distribution, and reproduction in any medium, provided the original work is properly cited.
} 


\section{Introduction}

Native social work educators of South Asian origin and well-meaning western educators and international development specialists have harangued for a while about the indigenisation of social work in these countries or absence of any initiatives in the direction of building native social work practice. Some exhaustive written material exists around the exporting of western social work model and lacklustre assimilation of the same within the Asian region. Our purpose is not so much to review the process of indigenisation or lack of it but to reckon the development trajectory of social work pedagogy, as a western form and its burgeoning impact in the current South Asian national universities and colleges.

The three of us, associated with this study, represent three South Asian countries with prolonged work experience in South Asia and South-East Asia and the Western World. The study has utilised a combination of methodsdesk review, analysis of email communications and our reflections in a range of settings including international conferences and symposiums. We began with a desk review and a flexible research methodology that allowed us to foster reflection, undertake preliminary analysis, and thereafter probe further into the concerns with colleagues in Asian social work. The study is divided into the following sections. It begins with a brief description of the methodology employed for this study. Besides, it includes a detailed note on our positionality and reflexivity as authors. Following this, it presents a very brief review of scholarship relevant to this topic. Then the study goes on to offer an overview of the development of social work in the South Asian region with specific country details. In the penultimate section, it presents the changing values in Asia, contradictions and the value of the collective. The last section deals with the conclusions.

\section{Methodology}

A desk review or literature review is primarily described as a way to synthesise previous research systematically (Snyder, 2019). Such reviews of previous research findings allow processes such as information accrual, collation, theming and analysis to occur. Thus, a resultant renewed perspective assists us in sharpening our research questions. Our methodology would be described as opportunistic or emergent (Brady, 2011). We understand that opportunistic or emergent sampling transpires when researchers start making sampling decisions during their phase of research. As we gained a greater understanding of the phenomena within our settings, we needed more views and information to support or offer contradictions around our arguments. The voice of Asian social work is consolidated from ten academics from Bangladesh, India, Sri Lanka and Nepal, using email trails. All our respondents are involved in teaching and research at the university level. Our iterative reflections helped us to analyse the data and to sharpen our arguments. Our analysis pointed to the need to connect and communicate with fellow academics in the Asian social work scene for a further view to support or refute our arguments. The personal communications from our respondents have been relevantly analysed and absorbed into this study. Our teaching tools and our pedagogical influences have, to a great extent, contributed to the current slant in this study. Methodological limitations include reliance on secondary data from Pakistan, limited information on the experience of Kabul University, Afghanistan -a nation still volatile and a cursory view of the Maldivian situation and nascent welfare-related course development in Bhutan.

The study has certain limitations, especially the small number of respondents from different South Asian countries. Though 20 questionnaires were sent out to potential respondents, only ten questionnaires were received with full responses within the stipulated time. There is no representative that we could meet in person from Pakistan, Afghanistan, Maldives and Bhutan in the last two years in conferences that we have attended. We enriched the discussion 
on the above countries through secondary data and personal communications.

We discuss our positionality and reflexivity in the following sub-section.

\section{Our Positionality and Reflexivity}

Three of us subjected ourselves as participant researchers so that we use our right to critique from within. A belief exists that the assumptions, motivations, narratives and the relations which are part of the researcher's backstage', influence the research process (Mc Corkel and Myers, 2003, pp. 199-231). A stated position in sociological research is reflexivity. The concept challenges all epistemological assumptions regarding the subjective production of knowledge and therefore, useful for social research (Dowling, 2009; McCorkel and Myers, 2003). The concept of positionality argues that there has to be a candid acceptance of researcher's identity and values that state researcher's location in relation to the subjects in the study. It became imperative to tease out our own 'reflexivity, positionality, privilege and situated knowledge' through transparency and rigour (Townson \& Pulla, 2015, p. 33; see also, Bhattacharyya et al., 2018).

We are aware that undertaking reflexivity allowed us to capture the subtle and nuanced yet ontological experiences specific to ourselves (Salzman, 2002). Thus, we declare our positionality as social work academics with over thirty years of intensive experience in social work education. Our distinctive experience is further strengthened by our teaching and mentoring across other western nations such as Australia and Canada and South-East Asian nation such as Malaysia. We further declare that our positionality also included the privileged position of being teachers in the Third World. We held western books in our hands. We are aware that there is power in a personal narrative. As a team of authors, we identified three attributes common to us, that is, (1). selfawareness, (2). critical reflexivity, and (3). analytical thinking that are considered integral to social work teaching and practice (Urdang, 2010). In social work, reflexivity, positionality, privilege, situated knowledge and one's own perceptions matter a great deal and seem to be intrinsically woven (Townson and Pulla, 2015). Townson and Pulla further argue:

The profession of social work has an inbuilt capacity for self-reflective process. Our thoughts on our own world and our knowledge and experiences appear to influence our responses to the people whom we serve. The question that clearly needs to be raised is: has this knowledge of the world distorted/influenced our perceptions of another individual's reality/truth? (Townson and Pulla, 2015: 31-48).

Reflexivity, on the other hand, can be described as circular by nature due to interaction and composed knowledge being a continuous activity (Bhattacharyya et al., 2018). 'Knowledge gets constructed by [the] interaction between the questioner and the world' (Takacs, 2003, p.31).

Social psychologist George Herbert Mead (cited by Salzman,2002, p. 806) describes reflexivity as the turning-back of [an] experience [or social interaction] of the individual upon himself.... which enable[s] the individual to take the attitude of the other toward himself which he states has the capacity for the individual to become more self-aware, create shifts in thinking and knowledge baselines and gain more understanding and insights.

Occasionally, our parallel thinking allowed us to bring about interpretative, blended innovations in the field that was limited response to a situation in field practice, such as understanding the traditional community strengths 'Guthi' in the Newar community and respecting their ties to their land and combining it with the overarching concepts of strengths-based practice (Pulla, 2017).

There are other crucial elements to reflexivity, and one of them is around the social worker/ researcher holding 'biases' or making conscious efforts to work through and eliminate them. Biases stem 'not from having ethical and political positions - this is inevitable - but from not acknowledging them' (Griffith, 1998, p. 133). In 
its bare essence, reflexivity simply asks the question: "How do we know what we know?" Hence, asking and then reflecting on this question allows for the deconstruction of our positionality (Raju, 2002), and we think it is crucial in social work.

Reflexivity and being in the ground of reality allows good scholarship to discern between one's own beliefs and opinions. The project of writing began with reflections on the theory of knowledge and practice methodologies of the west that continue to be in vogue in South Asia and still persists. If India alone is an example, we have over 526 schools of social work according to Professor Sanjai Bhatt, the President of National Association of Professional Social Workers in India (Bhatt \& Phukan, 2015). He is undertaking another survey this year to update the number of new schools of social work. This study reflects our combined epistemology. Our rapid literature review produced some gaps and ways by which the indigenous conceptualisation is explained. Triangulation of our thoughts, positionalities, and reflexivity is evident throughout the study.

\section{Indigenous Social Work Debate in South Asia}

The argument for indigenous social work crops up relevantly in non-western cultures, which are primarily previous colonies that for hundreds of years witnessed the exploitation of people through colonial governance. Western supporters of the indigenous standpoint in former colonies intentionally couch their argument in human rights and social justice framework (Briskman, 2003; Gray, Bird, \& Coates, 2008). One argument is that modernist social work is no good for approaching indigenous peoples as it is insensitive in dealing with the indigenous people's cultural space. It neither fits into the cultural realities of other diverse societies across the world, despite airing freely its claims to fit into local situations (Bird \& Gray, 2014). The bullet points of the box is an attempt to what entails an indigenous social work approach.

\section{What Would the Indigenous Social Work Approach Mean?}

- that social work practice should be locally relevant, though the knowledge of socia work may be borrowed from some other culture (Weaver, 2014)

- that indigenisation as a process of de-westernisation may stress a critical review of the applicability of Western theories, models, methods and skills to make social work education more responsive and relevant to the realities of the local space (Leyson, Pablo \& Nicolas, 2014)

- that which refers to modernisation in the developing world through the process of adapting imported ideas to fit local needs (Resnick, 1976: 22).

- the creation or building of a domestic model of social work in the light of the social, cultural, economic characteristics of a particular country (Ragab 1982: 136) and as a model that 'goes back to one's root to seek direction' (Ragab,1990: 43)

- that, 'for reasons relating to relevance and context, is incumbent on social work...to produce, in each country a model that is consistent with the local culture, political, economic and social realities, while hopefully retaining the core principles giving social work a distinctive character' (Cox,1991: 9).

- that the term 'Indigenisation' initially explained the development of social work in Africa. The term was borrowed by the United Nations (UN) and later used the term in the Fifth UN International Survey of Social Work Training to refer to the 'process of relating social work function and education to the cultural, economic, political and social realities of a particular country' (Shawky, 1972: 2).

- that 'Indigenisation' should start from within, using local culture and helping practices as the primary sources for knowledge, practice and development and thus, ensuring social work practice is 'culturally appropriate and relevant' (OseiHwedie,1993: 22). 
There is no denying that professional social work roles must serve the needs of people and to that extent appropriation of social work education to the local South Asian milieu-seems reasonable. While presenting a brief historical review of the introduction of social work in South Asian countries, the authors discuss the efforts made, including appropriation and modification in each South Asian nation. Views of our respondents gained through personal communications are relevantly interspersed. The following sections discuss the development of social work education in different countries of South Asia.

\section{Development of Social Work Education in South Asia}

Social work education was first introduced in the whole of South Asia in 1936 when the first school, Sir Dorabji Tata Graduate School of Social Work, later named as the Tata Institute of Social Sciences (TISS) was launched in the then Bombay (now known as Mumbai) in undivided India under the British rule. This school is the oldest in South Asia (Pathare, 2014). The new data has emerged from a recent study and is captured in the form of the following table, which is selfexplanatory (UNICEF, 2018, p. 24).

\begin{tabular}{|c|c|c|c|c|c|c|c|}
\hline Country & $\begin{array}{l}\text { Bachelor's } \\
\text { Social } \\
\text { Work }\end{array}$ & $\begin{array}{l}\text { Bachelor's } \\
\text { Other }\end{array}$ & $\begin{array}{l}\text { Master's } \\
\text { Social } \\
\text { Work }\end{array}$ & $\begin{array}{l}\text { Master's } \\
\text { Other }\end{array}$ & $\begin{array}{l}\text { PhD } \\
\text { Social } \\
\text { Work }\end{array}$ & $\begin{array}{l}\text { PhD } \\
\text { Other }\end{array}$ & Total \\
\hline Afghanistan & 1 & 0 & 0 & 0 & 0 & 0 & 1 \\
\hline Bangladesh & 4 & 1 & 7 & 0 & 1 & 0 & 13 \\
\hline Bhutan & 0 & 0 & 0 & 1 & 0 & 0 & 1 \\
\hline India & 144 & 3 & 270 & 15 & 6 & 1 & 439 \\
\hline Maldives & 1 & 3 & 0 & 1 & 0 & 0 & 5 \\
\hline Nepal & 6 & 4 & 4 & 4 & 0 & 0 & 18 \\
\hline Pakistan & 20 & 14 & 36 & 12 & 7 & 3 & 92 \\
\hline Sri Lanka & 2 & 4 & 1 & 7 & 0 & 0 & 14 \\
\hline $\begin{array}{l}\text { Degree } \\
\text { Total }\end{array}$ & 178 & 29 & 318 & 40 & 14 & 4 & 583 \\
\hline
\end{tabular}

The following discussion briefly records the introduction of social work curriculum in South Asian countries and relevant views of our academic respondents.

\section{Republic of India}

First two schools, TISS and Delhi School of Social Work (DSSW), followed by Kashi Vidyapeeth, and Lucknow as university departments began to nurture future social workers of India.

Out of the first eleven, seven were initiated by Christian organisations (Pathare, 2014). In the first phase of social work education in India, ten schools were established, of which the first seven were with the support of Christian missionaries. The social work curriculum offered in all these schools was largely traded in from the west, and the academic programmes were designed as per the curriculum of US universities. Many social work educators also obtained US degrees under various scholarships programmes (Pathare, 2014). India has done exceptionally well in the showcasing of nearly 526 schools of social work. Indian social work scholars have long explained the influence of Anglo-American social work in the social work curriculum introduced at different Indian universities and urged to overcome the American model by innovating indigenous social work (Pathare, 2014). Social work education and its growth and trends in Indian society have been analysed and assertions made about Western, indigenised and indigenous social work throughout history (Desai, 1985; Kumar, 2002; 
Mehta, 1986; Nagpaul, 1993; Wadia, 1968). To a great extent the work of US technical mission on Social Work Education and Technical Cooperation Mission (TCM), has provided the necessary impetus not only for India but to the neighbouring countries (Bhatt \& Phukan, 2015).

Pathare (2014) further wrote that the current state of social work education as a phase of reorganisation has been confronting difficult times resulting from globalisation and internationalisation.

Former Director of Tata Institute of Social Sciences and former Chairman, University Grants Commission, India, Professor Armaity Desai (1985) particularly commented that India largely followed a Western social work model and concerned itself with problems of urbanisation and industrialisation. She felt that in a non-industrial and substantially rural society like India, exploitation and injustices impact a vast majority of its people and lead them into a state of poverty. Desai was concerned that social work remained to a large extent on the periphery of the root cause of problems and mainly in urban areas. Indeed, there are several schools of social work with an emphasis on rural social work in India today. The year 1991-92 saw a rural university named Chitrakoot Gramodaya Vishvavidyalaya (CGV) signalling the importance of the development of villages. Alphonse, George and Moffatt (2008) suggested a paradigm shift was required in the Indian social work curriculum from its emphasis on clinical or generalist practice, including person-inenvironment fit to include further critical social work practice. Some Indian universities have included those courses that are mostly taught in American universities incorporating western terminology (Singh, Gumz, \& Crawley, 2010).

An experienced social work educator from Delhi University in her email shared that she has taught European and American social work history more than Indian history in the classroom. At the same time, she suggested that therapeutic models and understanding of the theoretical basis of social work like the concept of organised charity, and institutional and noninstitutional services that India undertook after independence was from western models. These, according to her, have suited a growing demand of industrialising country like India. She said that one can always learn from others' experiences and organised services; however, it is equally important to make adaptations in practice and build on the culture-specific knowledge.

There are many schools of social work in India which have redesigned their course curriculum according to the needs, problems, and changing values within the Indian society and thereby tried to make social work locally suited, culturally appropriate and relevantly blended. For example, TISS has reshaped and updated the social work curriculum to make it more contextual and socially relevant. The school has introduced foundation courses that focus on developing societies, their economy and politics and also their values and culture. Courses like social work in Dalit (the scheduled caste of India) and tribal studies and action; social work in livelihoods and entrepreneurship; social work in public health; social work in women-centred practice, etc. have been introduced, which have a substantial amount of India-related contents and may be described as a departure from the Western model. The new courses on antioppressive perspectives in the Indian context, social work schools in India have restructured the social work curriculum relevantly to meet the needs of social problems in the Indian context (Pathare, 2014).

A senior educator from Delhi based at Delhi School of Social Work feels that the Indian social work curriculum should be designed on the basis of socio-demographic, economic and cultural aspects of the country; the needs and situation of poverty alleviation taking a bigger chunk in the course work. She thinks that Gandhian philosophy and Rabindranath Tagore's rural development approach should be incorporated into the curriculum of social work. She further argued that Non-Government Organisations' (NGOs) activities as a source to innovate knowledge for new social work approaches, strategies and theories suitable in Indian contexts. When asked about the prospects of indigenous social work in India, she commented 
that she was in favour of a blended approach with a combination of both Western and local knowledge and local realities. She feels that it is a globalised society and issues/problems have their basis in international policies, and socioeconomic reforms.

A senior educator from Mangalore University, India decried that the social work profession still relied on the knowledge base created by Westerners. He said that he was not sure about the prospects of 'indigenous' social work in India. However, he did welcome academic resensitisation about ground realities and current curricula in social work schools in India. If there are evidence-based practices and research automatically, innovation will emerge. Another senior educator from Delhi University echoed the previous views as above but added further that:

social work education in India could be enriched from history and how people practice charities that brought in social reforms and conducted economic and social development. However, it needs to match the needs, problems and continuously evolving developmental demands within the Indian society. One must recognise that in areas such as disaster management, counselling and social work, social work with the elderly and the frail aged, school social work, women's welfare and development, human resource management, rural development, social work in health and others; there is clearly an emphasis on culture. Social work in the above areas has been improved and influenced as a result of evidence-based practice suggesting that a purely western pedagogy is not suitable for the Indian conditions. It is all about creative adaptations and making pedagogy relevant to the culture.

A senior social work educator referred to many tribal communities in the Indian society that possess their own templates for development, perhaps, much more advanced than the community development models that are taught in social work. Actual indigenous social work development, she contended is to let tribal communities design their development according to their social and cultural norms. She pointed towards the evidence of indigenous social work practice with Adivasis (Hill -tribes) that has had positive effects in many tribal regions.

The corresponding author recently met a group of research scholars at the Seventh National Congress of Social Work organised by NAPSWI in Lucknow (October 2019). The doctoral scholars opined that the pedagogy of social work in India continues to struggle to ensure its identity as an academic discipline and in the field practice; it is yet to make a mark. This, despite the mushrooming of several social work educational institutes and schools in India and ample opportunities for social work practice as a result of the increase in welfare expenditures from the government and through private sector participation. Prof. Sanjai Bhatt, in his personal communication, says:

Professional social work has clear intentions to promote social change and development and work towards the empowerment of the marginalised and the poor; however, I also see the struggle in the last 25 years, following the introduction of liberalisation, privatisation, and globalisation (LPG) culture. Now it is not clear where we are heading in terms of expansion of its boundaries owning everything under the sun as our intervention area, thereby having a symbolic presence in many areas of interventions. The Indianisation does not necessarily mean to bring all from the past, whether it is practically applicable or not. We need to connect with present cultural and social realities and search solutions therein.

Bhatt further said that: 'social work in India in many schools has brought in those variations and adaptations, but admittedly continue to utilise a large section of western writers in the absence of rather limited Indian authors in social work'. 


\section{Islamic Republic of Pakistan}

India was partitioned in 1947 as two independent countries, India and Pakistan. The partition of India caused a massive exodus of people from India to Pakistan and vice-versa along the line of religious identity. The rapid growth of slums, an increase of juvenile delinquency, fast spread of beggary, increase of unemployment and homelessness, breakdown of governance and other social issues throughout Pakistan indeed became very challenging for the government as it struggled to manage. Thus, the government decided to seek assistance from the United Nations (UN) in 1951 on at least two fronts: one was to rehabilitate Muslim refugees from India, and the other was to address the negative impacts of industrialisation and urbanisation that started immediately after the partition. The UN responded positively and sent a six-member experts' team in 1952 to investigate the overall situation (Akbar, 1965; Samad \& Das, 2014). The experts' team assessed the situation thoroughly and seemed to have recommended that social work education also be introduced in Pakistan to overcome the chaotic situation. The government accepted their recommendations and for the first time in the history of Pakistan introduced a welfare training course in Karachi in 1952 with UN technical help (Samad \& Das, 2014). Western-educated Anglo-American scholars who were members of the UN experts' team provided all technical assistance to design the curriculum introduced in Karachi in 1952. Certainly, the subsequent social work course curriculum has that American influence (Graham, Al-Krenawi \& Zaidi, 2007). As Malik \& Sarfaraz (2012, p. 213) commented:

In 1953, Miss Anna Mo Toll, a Swedish, medical social worker visited Karachi in response to the request from the Government of Pakistan to the UN. At that time, everyone was confused about the meaning and scope of 'Medical Social Work' and apprehensive of its success in a country where the basic needs took overwhelming priority over individual assistance. If lady health workers were given some training, it would serve that purpose. This was of course, totally unacceptable to the United Nations Training teams (Malik \& Sarfaraz, 2012 p. 213)

Social work education has changed little since its inception in Pakistan. It is still influenced by the western methods of problem-solving, though indigenous social work has sometimes been talked about. Moreover, indigenous literature and methodology suitable for social work practice in Pakistani society could not be developed (Rehmatullah, 2002). That it ought to have a flavour of the local culture and society and where possible some connection to its indigenous people, has been raised by the Curriculum Review Committee (2003). Units of study such as 'Pakistan society: its needs and problems', 'characteristics of Pakistani culture', 'Islam and social work' and others were suggested to be incorporated into the social work curriculum. This move possibly is a precursor to any localisation/ indigenisation effort of social work in the country. Currently, there are about centres of ten universities and a few other affiliated private colleges that offer postgraduate courses in social work (Eduvision, 2019). There are, however emerging social work research in Pakistan applying for both borrowed and local scholarship. For instance, in 2017 Aisha Shoukat and Venkat Rao Pulla, in their article titled Desert Dwellers' Meaning and Existence of Spirituality: A Gendered Case Study of Cholistan, Pakistan demonstrated how the desert dwellers of Cholistan use spirituality as a form of resilience to lead an eco-friendly life (Shoukat \& Pulla, 2017).

Their common religion, Islam bound the two wings of Pakistan, the West and the East, but the language and other cultural differences remained permanent niggles and caused tensions throughout. The East Pakistani's spoke largely Bengali as opposed to few other spoken languages in the Western parts of Pakistan, such as Punjabi, Pashtu, Sindhi and Urdu. Three decades prior to 1970, the relationships between the West and East Pakistan were tense and culminated into a civil war leading to 
Bangladesh's war for its own independence of erstwhile East Pakistan.

\section{People's Republic of Bangladesh}

Social work education in Bangladesh began in 1953 during Pakistani rule, based on the recommendations made by the same visiting UN team aiming to deal with the chaos and anarchy and also deteriorating law and order situation caused through the exodus of Indian Muslim migrants from India after the partion of Indian sub-continent in 1947 (Das, 2012; Das, 2013; Samad, 2009; Samad \& Das, 2014; Das, 2018). For the first time in the history of Bangladesh (erstwhile East Pakistan), a three-month training course on some aspects of social welfare was introduced in Dhaka in 1953. Later, in 1958, the 'College of Social Welfare and Research Centre' was established in Dhaka University. The College subsequently merged into the University under a new name- 'Institute of Social Welfare and Research' in 1973, after Bangladesh became a sovereign and independent country in 1971.

Ten social work programmes are currently functioning across the country (Das, 2012; Das, 2016; Samad \& Das, 2014). In the last sixty years in Bangladesh, the Western social work model is firmly compacted. Efforts to indigenise social work education have been sporadic, to begin with, and forsaken due to non-availability of literature that can be identified as indigenous. Also, there were limited efforts in research and developing local social work knowledge and skills (Das, 2012; Halim, 1992; Islam, 1992).

Bangladesh social work has shown some changes over the last few decades. These changes are not always aimed at making social work education indigenous instead of new Western-based courses are incorporated into the curricula. At the same time, some units of study are re-drawn, taking into account the local needs and culture into consideration. Some native scholars suggest that this may be regarded as an effort of indigenisation infusion courses such as 'life and society of Bangladesh', 'culture and social work contextualisation', 'approaches to community intervention', 'social problem analysis', 'social work camping', 'climate change, disaster management and rehabilitation', 'diversity, oppression and social work', 'guidance and counselling in social work', 'social work practice with family and children'have all been revamped to incorporate in the local issues. For examples, the Department of Social Work, Shahjajal University of Science and Technology, Bangladesh has identified a number of local community problems (floods, domestic violence against women, street children and many more) and carried out research applying theoretically informed and local knowledge (see, for example, Bhattacharyya et al., 2018; Das et al., 2015; 2016; 2020; Pulla and Das,2015).

The small indigenous lobby also seems to agree that one could not make a cent per cent indigenous as Bangladesh has somewhat limited indigenous knowledge. An experienced social work educator from the University of Rajshahi states that:

More practical courses are needed to be incorporated in curricula so that social work students can frequently interact with community people and understand the local culture, which will help them relate social work education to the culture of the locality. Extensive field training for the students, and continuous research on indigenous social work can help identify and discover locally based knowledge that may contribute to indigenous social work. I cannot give up... the prospects of indigenous social work education in Bangladesh are high. We are not putting in concerted, planned and purposive efforts in this direction.

Yet another senior educator from the University of Dhaka remarks:

We clearly lack indigenous teaching materials which is a serious barrier for the development of culturally relevant social work education. However, while making recognisable efforts towards indigenisation, it is equally important to understand and recognise the pervasive influence of globalisation and internationalisation on every aspect of life in Bangladesh. 
Das (2014) writes that social work in Bangladesh is an applied social science discipline. It has tremendous potentialities to be innovative to fight poverty, work with the underprivileged, and those deprived of basic human rights and living in rural areas, in urban slums, or working in tea garden areas. He goes on to comment:

The situation of these poor has been deteriorating further due to the process of globalisation and rapid urbanisation. The poor always remain outside the power structure and often fail to draw the attention of the powerful to their worsening conditions. A conventional social work approach like casework and group work fails to address the situation of the poor. Social workers in this context must work to organise the poor to be united in lodging a protest against their deprivation and discrimination, and also should demand their fundamental rights be fulfilled (Das, 2014, p. 81).

\section{Srilanka}

Social work education was introduced in Sri Lanka with the direct efforts of the Central Council of Social Services, a voluntary social service organisation, which established the first Institute of Social Work in 1952 (Herath, 2014). Later, in 1964, the Government's Department of Social Services established the Ceylon School of Social Work, recognising the need for trained social workers in Sri Lanka. The School was renamed as Sri Lanka School of Social Work in 1972 (Ranaweera, 2013; Vasudevan, 2014). It was upgraded and renamed as the National Institute of Social Development (NISD) by an Act of the Parliament of Sri Lanka in 1992, described as a milestone in the history of social work education in Sri Lanka (Herath, 2014; Vasudevan, 2014). In the year 2005, the Government of the Democratic, Socialist Republic of Sri Lanka, declared the National Institute of Social Development as a degree-awarding institution to develop higher education leading to the conferment of the Bachelor's degree in Social Work, and further with the Canadian International Development Agency (CIDA), implemented by the Queen's University,
Kingston, Canada. The National Institute of Social Development (NISD) began offering MSW in 2008 (Attanayake, 2016). Since 2013, a commendable step taken by the NISD is to offer Bachelor's degree in social work in native languages of Sri Lanka- Sinhala and Tamil in addition to English. Lack of locally produced literature poses a severe limitation to the development of Sri Lankan social work education. There are no textbooks written in Sinhala and Tamil languages. Social work educators generally use Western textbooks to teach the students, which also hampers the development of indigenous social work. By the second half of the seventies, internationalisation has affected Sri Lankan society. Professor Amarawansa Ranaweera, former Director of the NISD said that much dynamic societal change was discernable in the late seventies. According to him:

There was a decline in the size of the family. New employment opportunities emerged as garment factories began their production, people began to migrate to foreign countries for employment, especially the Gulf Market economy predominantly affected social values brought in more competition than cooperation. People have become more individualistic bordering on selfcenteredness. The universities received thousands of applications from aspirants. We did try our bit to get a curriculum in social work that is centred around some realities of Sri Lanka.

Shamini-Attanayake, the current Director General of NISD, who is also entrusted with the responsibility for guiding the Social Work education in Sri Lanka, said:

Social work education in Sri Lanka clearly follows Western model of social work, although we have taken some steps to localise to suit our contexts. I believe a Sri Lankan flavour is essential. I am of the firm belief that Western Social Work pedagogy cannot be used straight away. We need to make constant adaptations. 
A senior academic in NISD commented that research on indigenous social work is rather rare in Sri Lanka. The strong foundations of charity and taking care of the needy found in predominant religions of Sri Lanka, that is, Buddhism and Hinduism may be researched as they have high potential to contribute to more culture-specific re-modelling of the current curriculum of Social Work in Asia. Certainly, Sri Lanka, has progressed in introducing new courses like 'introduction to social work practice', 'law and human rights', 'economics for social work', 'social problems in Sri Lanka', 'community health', 'conflict resolution and social work', 'social development' and others have been creatively brought into the Sri Lankan curriculum (Herath, 2014).

\section{Nepal}

In Nepal, social work education was started with the Department of Social Work established in 1996 at St. Xavier's College with affiliation from Kathmandu University (Nikku, 2014; Yadav, 2018). Br. James F. Gates, introduced social work in the year 1987, which not only influenced but also had a particular Indian flavour, as it was supported by Nirmala Niketan-one of the prominent colleges of social work based in Mumbai. Three out of five universities, namely Tribhuvan, Kathmandu and Purbanchal, have permitted their affiliated colleges to offer social work programs. Nepal took its social work from Western countries, especially from the United States of America and the United Kingdom. Yadav, maintained, that the west-centric social work in Nepal struggled to build its credibility as a profession at the grassroots level. Yadav, therefore, attributes this to its origin, epistemology, and practice base (Yadav, 2018). Colonisation continues to influence the delivery of social work education in the global South, and therefore, it needs to be decolonised (Nikku, 2013 \& 2014). Though the origin of Nepalese social work is western imperialism, social work education has been modified over time as new courses like 'child rights, family and social work', 'law and social work', 'juvenile justice', 'industry and social work', 'Buddhism and social work' and many others have been included in the curriculum. It is believed that traditional 'individual centred model of social work practice' is not relevant in poverty- and conflictstricken country. Although indigenous social work education is stressed in the context of Nepalese society, its internationalisation has also been a reality (Nikku, 2014).

A senior social work educator from Nepal did not see social work education being influenced in any specific direction. He does not mind social work being influenced by the Western model as he said that not everything Western was bad. However, he believes in neither Western nor indigenous approach. Social work, to him, is very eclectic and this kind of distinction between Western and indigenous is not at all useful, especially when one is struggling to develop social work in a country where there is no state and societal recognition. Social work is seen as an elite course that can fetch UN jobs. He is, therefore, not worried about models. He further said that he was somewhat unsure about the prospects of indigenous social work in Nepal. However, he wanted Nepalese values to be included in social work training, such as the concept of Guthi (clan-based association).

While different views are expressed by social work educators from Nepal, the importance of making social work indigenous has not been rejected outright by any of our respondents. Most of them find it essential and suggested nurturing it to make social work education more effective.

\section{Afghanistan}

Active since 2016, an American based School of social work, Silberman School of Social Work supported by Family Health International (FHI)360 and the United States Agency for International Development (USAID) began initiating in Afghanistan, a Counseling Degree Partnership. According to website information, Kabul University has agreed to use this counselling program and train its students to protect the conflict-stricken Afghan society. However, social work education in Afghanistan is still at a rudimentary stage. NAPSWI has offered Afghanistan its support in developing social work courses (Nikku, 2014). 


\section{Other South Asian Countries}

In the Maldives, an education program has been designed to establish child, family and community support services across the country following the 2004 tsunami and also to tackle the situation resulting from the rapid socio-political change. Since 2007, Maldives College of Higher Education offers a one-year advanced certificate course in social service work, jointly planned and designed by the Ministry of Gender and Family of Maldives and the University of Newcastle, Australia and also supported by UNICEF (Plath, 2011). The Maldives University is slated to introduce BSW programme from 2020 intake.

\section{Changing Asia: Growing Contradictions}

This section is primarily based on the triangulated thoughts of the three authors associated with this study. We reiterate here that the indigenous arguments since inception of professional social work training in Asia were sprouted by a limited number of critics from within South Asian countries. These were equally supported by some collegaues of the west that genuinely continue to pine about the wipeout of anything indigenous that may have existed in these societies as a result of western influence. Mel Gray and her colleagues vociferously query the universalist models of social work that have been exported and indeed urges importing countries to consider indigenised and decolonial approach that could assist in focusing on local conditions and values (Gray, Coates \& Bird, 2008).

Critics have also claimed that this model has ensured that intellectual, cultural and corporate colonisation has been very vigorous (Gray et al., 2008; Haug, 2001; Nagpaul, 1993). Asian authors argued that the process has been ill-conceived as the exporters made no changes or adaptations before renting or giving away and that the importers did a lock stock and barrel embrace of the given models with no tinkering, or evaluation (Das, 2014). We accept that the universal applicability/ generalising ability of the western social work framework has been interrogated and the argument about Western social work practice possibly not being in sync with Asian values is valid. As authors, we have not come across re-structured social work educational content that relates to the needs of Asian societies and the myriad cultures that reside within.

Social work ought to be rooted in South Asian cultures makes a great argument. However, what would that look like? In Asia, many religious practices co-exist, predominantly Hinduism, Islam, Buddhism, Jainism, and Christianity; perhaps, the central element in the shared values of these religions is caring for those in need. While most South Asian nations are not mono-religious and contain some minorities, the political administration needs to be vigilant and make proactive adjustments and adaptations to preserve the pluralistic cultural ethos. India, Sri Lanka, Nepal, and Myanmar are clearly pluralistic societies. Bhutan was pluralistic until recently. Bangladesh, in its intent, allows for multiculturalism and multireligions. Maldives and Pakistan are Islamic countries within South Asia.

Additionally, non-Muslims living in the Maldives do not have citizenry rights. In Sri Lanka, the Sinhala, the Tamils and the Malabari Muslim population have been living together for a long time.

The Buddhists population which is the majority of Sri Lanka, here believe in rebirth. They believe that stopping rebirth would be the ultimate solution to human sufferings. Ranaweera (2013) suggests that rebirth occurs due to one's selfishness. To stop selfishness, one has to practice giving and sharing compassion towards others and loving-kindness towards all in the society.

What further contradictions are growing in these nations? Asia is also a scene for once pluralist nations becoming mono-religious. Nepal, until recently the Hindu Kingdom, decided to go secular in its constitution, wherein the first place there was no threat to its minority communities. After the deposition of the Monarch through the Maoist insurgency, the principle of secularism was brought into Nepal. Bhutan, the Shangri-La of gross national happiness where Hindus and Buddhist lived for a long time, the King and his Government decided 
to throw the Hindus away, and 100,000 of them returned to Nepal to languish in refugee camps for over twenty-five years (Pulla, 2016; Pulla \& Woods, 2016). Tibetan refugees in India live mostly in Delhi, Kathmandu and Dharmshala, India (Kharel, \& Pulla2014).

It is our belief that the Western- model of social work so far followed in South Asian regions by itself has not been very successful in addressing the diverse socioeconomic and psychological problems that have afflicted the people of this region (Nagpaul, 1993, Shek, 2017). However, adaptations, integrations seem to have worked in addition to sporadic efforts undertaken by South Asian scholars to make social work education relevant in their respective countries. Local needs and codes of conduct have not fully emerged but seem to appear with assistance from transnational social work practiceemerging and building transnational social work scholarship (Nikku \& Pulla, 2014). This study argues that it is crucial to relate social work education to local culture to adequately benefit its people, and this is perhaps, the only reason why South Asian academic and supporters elsewhere of indigenous social work keep the question of indigenous social work alive.

\section{Undermining the Values of the Collective}

A major criticism has been that Western social work theories are grounded primarily in individualistic ideologies, not entirely applicable to Asian societies wherein still collectivistic features abound. The value of the collective, in many parts of Asia and much of the African nations, does not agree with individualised psychosocial interventions and methodologies advocated by the western form of social work that emerges from the predominance of liberal individualism. The authors of this study contend that family continues to play an essential role in providing care to the children, old aged, people with disabilities and the sick and the distressed in most Asian countries. Western view of mental health and wellbeing is not considered an entirely a private individual matter in this context. This albeit, one notices weakening of cultural and traditional values such as filial piety and familism in Asia (Pulla, 2014; Shek, 2017), and a gradual increase of quick assimilation of western values such as individualism.

Western family therapies may need modification because Asians are not so expressive, and they tend to avoid interpersonal confrontation within the family (Shek, 2017: 3).

The western focus on the individual client is also receiving challenges. Migrant flows and people movements into the western societies from South Asia and the Horn of Africa, from culturally and linguistically different communities into largely Anglo Saxon background, are bringing with them their communitarian collectivist values (Gopalkrishnan \& Pulla, 2016). The ethnic diversity in western societies like the USA, UK, Germany, Netherlands, France, Australia and New Zealand is changing drastically. Migrants from the developing world that have exercised choice to move from birth countries have enriched the receiving nations. The combined presence of migrants and the refugees have contributed to higher productivity in the west. These migrant populations are expected to show quick assimilation and integration into the receiving societies. There is a window of opportunity to understand and appreciate the collectivist cultural orientation of many of these migrants now living in the western nations. In native societies, when people sometimes feel powerless and depressed, display suicidal ideation and other clinical conditions, they readily do not become the clients of professional social workers. Informal services such as family supports, elders within the communities legitimately practises alternate medicine, and presence of the traditional healing systems offer an excellent cover for them. Definitive roles of culture with ritual and tradition appear to provide these practices in Asian societies. Migrant clients, even in the western countries, do bring with them some of those resources. It is here, the discourse of culturally relevant social work within the dominant paradigm becomes relevant. Critiques argue, that despite the culture-relevant paradigm in the west, tangible outcomes for diverse groups of people are not 
forthcoming (Samad \& Das, 2014; Gray \& Coates, 2008; Tsang \& Yan, 2001; Yip, 2004).

\section{Conclusion}

With the inevitability of the globalisation, neoliberal policies, weakening welfare states, the agenda of environmental, global or international social work assumes importance. A relevant question at this point of time is: are there any lessons western social work practice that intersects with the native migrants' values, their aspirations and anxieties in their new settings could suggest for Asia? Asia too significantly is changing its demographics as a result of displacement of people and migration within Asia and also the migration of people from North-East Africa to Asian countries such as India.

While social work has plenty of opportunities to submerge and involve itself in local contexts, in Asia, social work is too weak to resist the neoliberal policies of the governments (Yadav, 2018). The principle in social work is about causing transformative, emancipative, and development-oriented social work practice to uplift the quality of life of its population (Yadav, 2018).

The legacy of Western-influenced social work education in the region clearly continues, despite criticism from different quarters about its effectiveness. However, from the very beginning, some social work scholars in South Asian countries appear to have raised the need for indigenous Social Work. The respondent academics of our study saw a somewhat limited role in introducing variations and adaptations relevant to their context in relation to social work education.

It appears that social work education has not gained the necessary importance as professional one that can work with societal problems in South Asian nations. The state of social work in these countries substantially funds social welfare and social development. The professional degrees of BSW and MSW are yet to become mandatory qualifications for a variety of social welfare positions requiring the incumbents to work with a repertoire of social work skills. Our respondents have opined that it is treated as an inferior academic discipline, less prestigious, less influential and less applicable. Consequently, social work as a profession remains to be recognised too. The silver line seems to be that despite these dismal situation, social work graduates are generally receiving employment in several sectors of welfare in government agencies and non-government organisations and also with corporate houses and in factories, mines, plantations and other industries.

No social work educator from South Asia disagrees with the notions of indigenous or localised social work but cautiously suggest that the impacts of globalisation and internationalisation cannot be ignored. Our respondents suggest adopting a blended approach to social work education in South Asia. They think there is a lot that can be brought in by way of adaptation if the cultural elements are accorded due importance in the frameworks. It is also pointed out that the very perspective of 'whatever is Western is always bad' is misleading and absurd. We reiterate that there is a great need for a critical reflection and reflexivity within the social work fraternities within Asia. Certainly, social workers exchange of views through conferences, workshops and symposiums in each nation and reflective writing has also been recommended.

\section{References}

Akbar, M. A. (1965). Elements of social welfare. College of Social Welfare and Research, Dacca.

Alphonse, M., George, P. \& Moffatt, K. (2008). Redefining social work standards in the context of globalization: lessons from India.

International Social Work, 51(2), 145-158.

Attanayake, S (2016). Challengers of Social Work Education in Sri Lanka. International Journal of Social Work and Human Services Practice, 4 (5), 118 - 120, doi:

10.13189/ijrh.2016.040504.

Bhatt, S., and Phukan D. (2015). Social Work Education in India- A Resource Book, AlterNotes Press, New Delhi. 
Bhattacharyya, R., Das, T., Alam, F and Parvin Amina (2018). Researching Domestic Violence in Bangladesh: Critical Reflections, Journal Ethics and Social Welfare, 12(4), 314-329, https://doi.org/10.1080/17496535.2018.14588 89.

Bird, M. Y. \& Gray, M. (2014). Indigenous people and language of social work. In M. Gray, J. Coates, \& M. Y. Bird (Eds.), Indigenous social work around the world: Towards culturally relevant education and practice (p. 59). Ashgate Publishing Limited, Hampshire.

Brady, A. (2011). Opportunity sampling. In V. Jupp (ed.). The SAGE Dictionary of Social Research Methods. London: SAGE Publications. https://dx.doi.org/10.4135/9780857020116.

Briskman, L. (2003). The black grapevine: Aboriginal activism and the stolen generations. The Federation Press, Sydney.

Cox, D. (1991). Social work education in the Asia-Pacific Region. Asia Pacific Journal of Social Work, 1(1), 7-14.

Curriculum Review Committee for Higher Education. (2003). Review of social work curriculum. Ministry of Education, Government of Pakistan.

Das, T. K. (2012). Applicability and relevance of social work knowledge and skills in the context of Bangladesh. SUST Studies, 15(1), 45-52.

Das, T. K. (2013). Internationalization of social work education in Bangladesh. In T. Akimoto, \& K. Matsuo (Eds.), Internationalization of social work education in Asia (pp. 37-56). Social Work Research Institute, Asian Center for Welfare in Society (ACWelS), Japan College of Social Work, Tokyo: Asian and Pacific Association for Social Work Education (APASWE).

Das, T. K. (2014). Indigenization of social work education in Bangladesh. In T. Akimoto, \& K. Matsuo, (Eds.), Internationalization \& indigenization of social work education in Asia (pp. 39-60). Social Work Research Institute, Asian Center for Welfare in Society (ACWelS), Japan College of Social Work, Tokyo: Asian and Pacific Association for Social Work Education (APASWE).
Das, T. K. (2016). Innovative social work teaching and effective social work learning. In A. Azman, J. Sulaiman, P. S. J. Singh, M. T. Mohamad (Eds.). Contemporary Social Work Education, Training and Practices in the AsiaPacific Region (pp. 37-50). Institut Sosial Malaysia, Ministry of Women, Family and Community Development, Malaysia.

Das, T. K. (2018). Social work practice with abused married women. In L.Vilka, O. Bruvers, A. Abele, M. Lotko, \& I. Razgale (Eds.), Social Work Case Analysis: Global Perspective (pp. 3364). Rigas Stradina Universitate, Latvia.

Das, T., Alam, F., Bhattacharyya, R. and Parvin, A. (2015). Causes and Contexts of Domestic Violence: Tales of the Help Seeking Married Women in Sylhet, Bangladesh, Asian Social Work and Policy Review, 9(2), 163-176, DOI:10.1111/aswp.12055.

Das, T., Bhattacharyya, R. Alam, F., and Parvin, A. (2016). Domestic Violence in Sylhet, Bangladesh: Analysing the Experiences of Abused Women, Journal Social Change, 46 (1), 106-123, DOI: 10.1177/0049085715618561.

Das, T. (2018). Social Work Practice with Abused Married Women in Bangladesh. In Marika Lotko (Ed.). Social Work Case Analysis: Global Perspective: Collection of articles about experience on case work and social case management of eleven countries, (pp. 33-64) Rīga Stradinš̌ University, Publication, Rīga.

Das, T., Bhattacharyya, R. Alam, F., and Parvin, A. (2020). In-depth Semi-structured Interviewing: Researching Domestic Violence as a Public Health Issue in Bangladesh, SAGE Research Methods Cases Medicine \& Health, Disciplines: Public Health, Online ISBN: 9781529719840, DOI: https://dx.doi.org/10.4135/9781529719840.

Desai, A. S. (1985). The foundations of social work education in India and some issues. The Indian Journal of Social Work, 46(1), 41-57.

Dowling, R. (2009). Ethical issues in research. In Rob Kitchin and Nigel Thrift (Eds.). International Encyclopedia of Human Geography (pp. 595600). Elsevier, Oxford. 
Educational Vision (2019). MA Social Work Universities and Colleges in Pakistan, Retrieved on 13 March 2020 from,

https://www.eduvision.edu.pk/institutionsoffering-social-work-with-field-social-sciencesat-master-ma-msc-level-in-pakistan-page-1

Gopalkrishnan N., Pulla V. (2016). Beyond cultural competence: Working across cultures in a globalized world. In V. Pulla (Ed.), The Lhotsampa People of Bhutan. Palgrave Macmillan, New York,https://doi.org/10.1057/9781137551429_ 8.

Graham, J. R., Al-Krenawi, A. \& Zaidi, S. (2007). Social work in Pakistan: Preliminary insights. International Social Work, 50(5), 627-640.

Gray, M. \& Coates, J. (2008). From

'Indigenization' to Cultural Relevance. In M. Gray, J. Coates, \& M. Y. Bird (Eds.), Indigenous social work around the world: Towards culturally relevant education and practice (pp. 13-30), Ashgate Publishing Limited, Hampshire.

Gray, M., Bird, M. Y. \& Coates, J.

(2008).Towards an understanding of indigenous Social work. In M. Gray, J. Coates, \& M.Y. Bird (Eds.). Indigenous social work around the world: Towards culturally relevant education and practice (pp. 49-50), Ashgate Publishing Limited, Hampshire.

Gray, M., Coates, J. \& Bird, M. Y. (Eds.) (2008). Indigenous social work around the world: Towards culturally relevant education and practice, Ashgate Publishing Limited, Hampshire.

Griffiths, M. (1998). Educational Research for Social Justice: Getting off the Fence. Open University Press, Buckingham

Halim, M. A. (1992). Social work and practical training: Ideals and realities. In M. H. Rahman, A. S. M. N. Islam, M. A. Halim, \& M. A. S. Bhuiyan (Eds.). Field training in social work (pp. 42-48), Department of Social Work, University of Rajshahi.

Haug, E. (2001). Writing in the margins: Critical reflection on the emerging discourse of international social work. Unpublished MSW thesis. Faculty of Social Work, University of Calgary, Canada.

Herath, C. J. (2014). Evidence of indigenization of social work education in Sri Lanka. In T.T. Akimoto, \& K. Matsuo (Eds.), Internationalization \& indigenization of social work education in Asia (pp. 121-157). Social Work Research Institute, Asian Center for Welfare in Society (ACWelS), Japan College of Social Work, Asian and Pacific Association for Social Work Education (APASWE), Tokyo.

Islam, A. S. M. N. (1992). The role of social services department and development agencies in practical training. In M. H. Rahman, A. S. M. N. Islam, M. A. Halim, \& M. A. S. Bhuiyan (Eds.). Field training in social work (pp. 20-29), Department of Social Work, University of Rajshahi.

Kanchan Pd. Kharel, Venkat Pulla (2014). Building Resilient Communities through Bottom up Approach: Case Study of a Rural Education Centred NGO from Nepal. International Journal of Social Work and Human Services Practice, 2(3), 58 - 65. doi: 10.13189/ijrh.2014.020302.

Kumar, A. (2002). Social work in India: A 'bright' future? Indian Journal of Social Work, 63(1), 8089.

Leyson, A. T., Pablo, L. D. \& Nicolas, J. V. (2014). Social work education in the Philippines. In T. Akimoto, \& K. Matsuo (Eds.). Internationalization \& indigenization of social work education in Asia (pp. 255-300). Social Work Research Institute, Asian Center for Welfare in Society (ACWelS), Japan College of Social Work, Asian and Pacific Association for Social Work Education (APASWE), Tokyo.

Malik, A. \& Sarfaraz, S. F. (2012). Social Work Practice in Health Care with Special Reference to Pakistan Pakistan Journal of Commerce and Social Sciences6 (1), 210-215.

Mehta, B. H. (1986). Historical background of social work in India. Indian Journal of Social Work, 46, 441-455.

McCorkel, Jill A. and Kristen Myers (2003). What Difference Does Difference Make? Position and 
Privilege in the Field. Qualitative Sociology 26, 199.

Midgley, J. (1981). Professional imperialism: Social work in the Third World. Heinemann Educational Books, London.

Nagpaul, H. (1993). Analysis of social work teaching material from India: The need for indigenous foundations. International Social Work, 36(3), 207-220.

Nikku, B. R. (2013). Internationalization of social work education in Asia: A case study of Nepal School of social work. In T. Akimoto, \& K. Matsuo, (Eds.). Internationalization of social work education in Asia (pp.151-193). Social Work Research Institute, Asian Center for Welfare in Society (ACWelS), Japan College of Social Work, Tokyo: Asian and Pacific Association for Social Work Education (APASWE).

Nikku, B. R. (2014). Indigenization of social work in Nepal: Rhetoric and reality. In T. Akimoto, \& K. Matsuo (Eds.). Internationalization \& indigenization of social work education in Asia (pp. 105-120). Social Work Research Institute, Asian Center for Welfare in Society (ACWelS), Japan College of Social Work, Asian and Pacific Association for Social Work Education (APASWE), Tokyo.

Nikku, B. R. (2014). Social work education in South Asia: Diverse, dynamic and disjointed. In C. Noble, H. Strauss \& B. Littlechild (Eds.). Global social work: Crossing borders, blurring boundaries (pp. 97-112). Sydney University Press, Sydney, NSW.

Nikku, B. R., \& Pulla, V. (2014). Global agenda for social work and social development: Voices of the social work educators from Asia. International Social Work, 57(4), 373-385.

Osei-Hwedie, K. (1993). The challenges of social work in Africa: Starting the indigenization Process. Journal of Social Development in Africa, 8(1), 19-30.

Pathare, S. (2014).Social work education in India. In T. Akimoto, \& K. Matsuo (Eds.). Internationalization \& indigenization of social work education in Asia (pp. 183-254). Social
Work Research Institute, Asian Center for Welfare in Society (ACWelS), Japan College of Social Work, Asian and Pacific Association for Social Work Education (APASWE), Tokyo.

Pulla, V. (2014). Chapter 10: Spiritually Sensitive Social Work: The Road worth Taking Chapter. (pp.194-211), In Bala Raju Nikku and Zulkarnain Ahmad Hatta (eds.). Social Work Education and Practice: Scholarship and Innovations in the Asia Pacific, Primrose Hall, Australia.

Pulla, V. \& Das, T. K. (2015). Coping and resilience: Women headed households in Bangladesh floods. In V. Pulla \& B. B. Mamidi (Eds.). Some Aspects of Community Empowerment and Resilience (pp. 226-240). Allied Publishers Pvt. Ltd, New Delhi.

Pulla V. (2016). The Lhotsampa People of Bhutan. Palgrave Macmillan, New York

Pulla, V., \& Woods, J. (2016). The Lhotsampa in Australia: Their Spirituality for Coping and Resilience. Society and Culture in South Asia, 2(1), 59-78. https://doi.org/10.1177/2393861715608979. Pulla, V. (2017). Strengths-based approach in social work: A distinct ethical advantage. International Journal of Innovation, Creativity and Change, 3(2), 97-114.

Plath, D. (2011). Social work capacity building in the Maldives. In S. Stanley (Ed.), Social work in countries of the East (pp. 347-367). Nova Science, USA.

Raju, S. (2002). We are Different, but Can We Talk?, Gender, Place \& Culture: A Journal of Feminist Geography, 9 (2) pp. 173-177

Ragab, I. (1982). Authentization of social work in developing countries. Integrated Social Services Project, Egypt.

Ragab, I. (1990). How social work can take root in developing countries. Social Development Issues, 12(3), 38-51.

Ranaweera, A. (2013). Review and record of the history of social work education in Sri Lanka. In T. Akimoto, \& K. Matsuo (Eds.). Internationalization of social work education in 
Asia. Social Work Research Institute, Asian Center for Welfare in Society (ACWelS), Japan College of Social Work, Asian and Pacific Association for Social Work Education (APASWE), Tokyo.

Rehmatullah, S. (2002). Social welfare in Pakistan. Oxford University Press, London.

Resnick, R. P. (1976). Conscientization: An indigenous approach to international social work. International Social Work, 19 (2), 21-29.

Salzman, P, C. (2002), On reflexivity. American Anthropologist, 104(3), 805-813.

Samad, M. \& Das, T. K. (2014). Contextualizing social work practice in Bangladesh. In Nikku, B. R. \& A. H. Zulkarnain, (Eds.). Social work education and practice: scholarship and innovations in the Asia Pacific (pp. 72-96). Primrose Hall Publishing Group, Brisbane Australia.

Samad, M. (2009). Development of social work education in Bangladesh and need for AsiaPacific regional cooperation. Proceedings of Seoul International Social Work Conference, Seoul. Social Work Education and Practice Development, South Korea.

Snyder, H. (2019). Literature review as a research methodology: An overview and guidelines. Journal of Business Research, 104, 333-339.

Shawky, A. (1972). Social work education in Africa. International Social Work, 15(1), 3-16.

Shek, D., (2017), Editorial: A Snapshot of Social Work in the Asia-Pacific Region, The British Journal of Social Work,47(1), 1-8, https://doi.org/10.1093/bjsw/bcx007.

Singh, S., Gumz, E. Z. \& Crawley, B. C. (2010). Predicting India's future: Does it justify the exportation of US social work education? Social Work Education, 30(7), 861-873.

Shoukat, A., \& Pulla, V. R. (2017). Desert Dwellers' Meaning and Existence of Spirituality: A Gendered Case Study of Cholistan, Pakistan. Space and Culture, India, 5(2), 32-46. https://doi.org/10.20896/saci.v5i2.278.
Takacs, D, (2003). How Does Your Positionality Bias Your Epistemology? The New Higher Education Journal Thought \& Action pp. 27-38.

Townson, L. \& Pulla, V. (2015), Preparing Social Workers for Empowerment: The Place of Positionality and its Continual Intricacies'. (pp. 30-48). In Pulla, V. and Mamidi, B.B. (ed). Some Aspects of Community Empowerment and Resilience Allied Publishers Pvt. Ltd, New Delhi

Tsang, A. K. T., \& Yan, M. C. (2001).Chinese corpus, western application: The Chinese strategy of engagement with western social work discourse. International Social Work, 44(4), 433-454.

University Grants Commission. (1965). Social work education in Indian universities. New Delhi.

Urdang, E. (2010). Awareness of self-A critical tool. Social Work Education, 29(5), 523-538.

United Nations Children's Fund, State of the Social Service Workforce in South Asia (2018). UNICEF, Kathmandu, Pages 20. Retrieved on 01 January 2020 from, https://www.unicef.org/about/annualreport/fil es/ROSA_2018_ROAR.pdf

Vasudevan, V. (2014). Indigenization of field practice in social work education in Sri Lanka. In T. Akimoto, \& K. Matsuo (Eds.), Internationalization \& Indigenization of Social Work Education in Asia (pp. 159-181). Social Work Research Institute, Asian Center for Welfare in Society (ACWelS), Japan College of Social Work, Asian and Pacific Association for Social Work Education (APASWE), Tokyo.

Wadia, A. R. (1968). History and philosophy of social work in India. Allied Publishers, Bombay.

Weaver, H. N. (2014). Indigenous social work in the United States: Reflections on Indian Tacos, Trojan Horses and Canoes filled with indigenous revolutionaries. In M. Gray, J. Coates, \& M.Y. Bird, (Eds.), Indigenous social work around the world: Towards culturally relevant education and practice(p.71), Ashgate Publishing Limited, Hampshire. 
Yadav, R. (2018). Shifting the Ground in Nepali Social Work: A Decolonizing Perspective. Critical Social Work, 19(2), 76-91.

Yip, K. (2004). A Chinese cultural critique of the global qualifying standards for social work education. Social Work Education, 23(5), 597612.

\section{Acknowledgements}

The authors sincerely express their gratitude to Professor M. Jalal Uddin, and Professor Muhammad Samad, University of Dhaka, Professor P. Ilango, Bharathidasan University, Dr D. K. Lal Das, Formerly College of Social Work, Hyderabad, Dr. Suresh Pathare, Director, CSRD-
Institute of Social Work and Research, Dr. Kalpana Goel, University of South Australia, Dr. Richa Chowdhury, Dr.Bhim Rao Ambedkar College, University of Delhi, Mrs. V. Vasudevan, National Institute of Social Development, NISD, Sri Lanka, Prof. Sanjai Bhatt, Delhi School of Social Work, University of Delhi, Ms. Amina Pervin and M. Fakhrul Alam, Shahjalal University of Science \& Technology, Sylhet, Bangladesh for their precious contributions to this study. We are also grateful to many of our colleagues with whom we had discussions, email exchanges and telephone conversations. The first author is particularly grateful to doctoral scholars who gave their views. 